\title{
THE LANGUAGE JUNGLE: SPEECH TRAINING IN A NATURAL LEARNING ARENA
}

\begin{abstract}
The project presented is one in cooperation with Tusenbein (Centipede), our close partner preschool near Mo i Rana, a town in Northern Norway. Here they have constructed a climbing jungle in the woods not far from the preschool, where the children can work with social skills, bodily-kinesthetic skills, and linguistic skills; they call it the Language Jungle. As a teacher in preschool teacher training, it is important to learn more about what the preschools find necessary to work with, and the methodology incorporated. In order to learn more about this project, I have employed fieldwork methodology; spending time in the field, to learn more about how a climbing jungle can be an arena for speech training.
\end{abstract}

Keywords: Holistic learning, language training, Norwegian preschool.

\section{Introduction}

Tusenbein (Centipede) Preschool outside Mo i Rana in Northern Norway wishes to use the outdoor environment actively in its educational activities. Therefore, the staff has set up a climbing jungle in the woods a distance from the preschool. The staff does not want to merely work to stimulate motor development outdoors; they also want to work to link linguistic activities to the motor challenges. Hence the name Language Jungle.

The preschool has social skills, languages, and outdoor life as main areas of focus. "Outdoors, the children use their bodies and their senses differently than indoors" [author's translation] (Tusenbein, 2018). The outdoor arena is an arena for communication and interaction, an arena where the children must relate to each other and care about each other and learn to make their own choices. Thus, the three main areas of focus 
can be combined in the daily routines, and through the development of the Language Jungle be given an even clearer focus.

My role has been to evaluate the process of construction and implementation of the Language Jungle, using fieldwork methodology to uncover whether the preschool achieved its goal, and the staff succeeded in creating an environment outdoors where the children could develop both motor and language skills in a natural way.

\section{Method and design}

A climbing jungle is a playground made up from trees and apparatus, with built-up obstacles and challenges that invite the children to explore, climb, balance, crawl, spin, hang, and do gymnastics; a jungle that is not impenetrable, but challenging and stimulating for children's sensory motor development. By stimulating the senses, the children acquire basic skills for body awareness and coordinative properties such as balance, coordination, speed and strength (Jagtøien and Hansen, 2000, pp. 71-77). Tusenbein's staff wanted to use their climbing jungle to give the children a varied environment where they must learn to interact and take each other into account, where they face challenges both in motor and language skills. “... if we manage to change practice in relation to language-stimulating tasks outdoors" [author's translation], is a learning outcome taken from an application for support for the Language Jungle project (Tusenbein, 2009). One of the goals of action learning or action research is precisely to create change or renewal in oneself or in an institution. "Action research is a very practical way of looking at your own work in order to check whether it is like you would like it to be" (McNiff 2005, p. 5). Action learning implies that a teacher asks questions about his or her own practice, and finds the answers him- or herself (Tiller, 2006, p. 52).

Action learning is what teachers do in their everyday lives, while action research is something a researcher brings in from outside and interacts with the people of the school on a daily basis (Tiller 2006, p. 29). I was invited into the project as a researcher, but this was not my project, so based on this definition, the project cannot be defined as action research. May Britt Postholm writes that there may be practitioners who initiate action research efforts based on their problem areas, and in order to establish this mutual relationship between researchers and research participants, she uses the term interactive action research. Postholm introduces this collective term for both action research and action learning (Postholm 2006, p. 13). The Language Jungle is the preschool's project, and it is their ideas that will be put into practice. To complete the project and achieve its goals, Tusenbein Preschool needs to change its practice and use the outdoor environment 
more consciously in language stimulation work. The Language Jungle project may thus be defined as interactive action research.

My role in the project described is that of the researcher to evaluate it, thus the evaluation research method is the chosen approach. Evaluation research is a method concerned with "exploring effects of different types of measures and influencing, changing or describing processes" (Sverdrup, 2002, p. 19). It has become a central area as a result of the need to investigate how a project progresses; it is about establishing experiences of effort and change. The survey undertaken is based on the preschool's own goals, and is an investigation of whether or not they have been achieved. The investigation is a qualitative survey in which method and design are defined based on the relevant issues.

The method used to collect data material in the Language Jungle project was fieldwork. On the basis of querying, listening, participating, and observing, the field researcher collects the required data material, which must then be interpreted and analysed (Hammersley and Atkinson, 2004, pp. 8-9). In order to get to know Tusenbein Preschool and to carry out research, the preschool and Language Jungle have been visited regularly throughout the project period, and also after the project period was over. My aim has been to observe the development of the project, and to observe how children interact and use language when playing in the Language Jungle. The field researcher seeks to see the world as the participators in the field see it; she takes part in the activities that take place, while observing what the various participants do, and collecting data by presence in the field studied. In this way, the field researcher tries to achieve the most naturalistic approach to the substance (Law, 2007, p. 30, Gubrium and Holstein, 1997, pp. 24-25).

An insight into a developing process has been obtained through the important tools of qualitative interviews and dialogue. By selecting interviewees with relevant competence of topic and project implementation, one may easier understand the informant's evaluation off the given topic (Sverdrup, 2002, p. 122). Planning an interview, it is important to clearly determine both contents and goals. Six Tusenbein employees were interviewed before the project was implemented, during the implementation, and finally after the project completion. The goals of the interviews were that informants on their own accord reflect over the language stimulation work taking place in the preschool's outdoor learning environment, their pre-project anticipations, what they learned during the project, and whether they are using the outdoor environment more consciously in language stimulation work after the project is finished.

In my work, I have used a logbook, where the observations and notes from conversations and interviews with both children and staff were duly 
noted along the way. As a researcher, I want to be close to the informants, while trying to be neutral enough to reflect on and find meaning in the information I receive (Vedeler, 2000, pp. 31-35). The data material for the evaluation research is my logbook, interview transcriptions, photos, children's drawings, and documents provided by the preschool.

Interpretations, assessments and reflections of the information gathered was the next step. "The first step in the analysis process is naturally a thorough reading (probably several times) of all the data to get to know them well" [author's translation] (Hammersley and Atkinson, 2006, p. 238). In connection with fieldwork, there will be a large amount of data that needs to be reviewed to search for relationships across the data. The goal is to identify key features and important findings that can illuminate the issues. Data analysis does not need to be a separate part of the research process; it takes place in parallel with data collection, and continues until writing reports, articles and books (Hammersley and Atkinson, 2006, p. 233).

In this article the focus will be on how Tusenbein Preschool manages to create an environment outdoors where the children can develop both motor and language skills in a natural way. I will also say something about what happened in the Language Jungle after the project period was over.

\section{The Language Jungle}

Tusenbein Preschool has three main areas of focus, where language is one. The term language training is preferably used for systematic and organized introduction to foreign languages and mother tongue written languages. However, the mother tongue is not something one acquires automatically either. Children need both language impulses and language help, which they receive to varying degrees; often without the adults being conscious about this. In 2005, Grøver Aukrust wrote a report about early language training commissioned by the Ministry of Education and Research. Here she explains that children's vocabulary show a relative stability from the age of six to the end of their education; in the way that the child, who has a small vocabulary when he or she starts school, also has a limited vocabulary when finishing school. On the other hand, the child with an extensive vocabulary when he or she starts school will continue to develop this and finish school with an even more extensive vocabulary and good reading skills (2005, p. 44). This stresses the importance of the preschools' work with speech training.

The other areas of main focus for Tusenbein are social competence, and outdoor activities. Growing children need to use their bodies; they need to develop their bodily-kinaesthetic or motor skills. Outdoors they can run faster, jump higher, climb higher, and play wilder. The children need 
to work with social competence; they must learn how to cooperate with each other, how to help each other, and to grow up to be a part of our community.

Nature is also a place to work with linguistic skills, as the children necessarily have to communicate when playing together. The child is more observant outdoors, where he or she pays attention and experiences the joy of discovery. Outdoors, the children build a concrete understanding of concepts, and they use their senses discovering the various things they come across: They taste, they touch, and they listen to; and this way they acquire the words and their meaning. Blueberries are sweet, nettles sting, moss is soft, the marsh is wet, and the bonfire is hot; and it might be slippery to balance on a wet log or walk on ice. These physical experiences ensure that the children learn new and appropriate language in a natural and meaningful context, where senses, emotions, and understanding are also stimulated. Communicative skills develop, as the children may need to do some research themselves to find the answers to their wonder; they need to argue, listen, and wait their turn. This way they learn about forms of communication, and by discussing and explaining, learn more about the world around them, as well as an increased conceptual understanding (Hilmo, Holter og Langholm 2006). Semiotic meditation is about the different cultural knowledge and valuables the child acquires through social practice. Everyday language and conversations is the central learning arena (Vygotsky 1978, Gjems and Løkken 2011, p. 49). It is important that the child is in an environment where language is used actively, thus acquiring new terms and phrases in a meaningful context. The playground is the child's natural learning arena. Through playing, the child discovers the world around, using language and body. This was the background for Tusenbein Preschool's decision to build a climbing jungle, where the children would face challenges both in motor and language skills, hence the name Language Jungle. Staff, parents, and children participated actively throughout the process. In the initial phase, it was ensured that some of the apparatus were completed, so that the children could play while construction continued. In this way, the preschool created a motivation for the children to visit the Language Jungle while it was still under construction.

When visiting the Language Jungle at this early stage, some of the children would want to play, while other children were actively involved in the work with the adults. The children helped to strip wood to be used in the construction of new apparatus, and they helped to carry stones away from the area. The children present during the construction period are able to test the apparatus under way, and may give immediate feedback on the functionality; as the five year old who stood watching the youngest children having problems climbing a somewhat steep hill: "It is easier for 
the smallest ones to enter from the other side, because it is easier to walk there. First we have to remove the twigs and branches". He then proceeded to remove the branches (personal observation, 2011). Children are solutionoriented; they see a problem and come up with constructive suggestions for how it may be solved. They put words to their thoughts and they explain what they mean. When the adults take the children seriously and listen to what they have to say, they help the children develop confidence in their own participation and problem solving. The children involved in such work gain experience in seeing different types of tools in use. They learn how to handle a sheath knife, they learn the names of tools not only because they have seen pictures of them, but because they know how they feel, how heavy they are, what they are used for, how they are used, how they sound, and they learn to respect dangerous tools; all due to that they have seen them in use.

At the same time as the apparatus in the climbing jungle were developed, some of the preschool teachers had the main responsibility for developing and testing language-stimulating equipment that would be used outdoors. Metal signs were set up around the Language Jungle, with accompanying magnetic photo cards with different types of tasks. Options may be cards with pictures of things that rhyme, geometrical forms, animals and their footprints, fairytale pictures, songs, numbers, letters, and numerous other activities. Boxes of physical objects to be used for tactile activities were assembled. All the senses that are important for learning, the visual, auditory, kinesthetic and the tactile, should be stimulated in the Language Jungle. In addition, this work was, and is, a common responsibility for the staff. On planning days, they have focused on language material through exchange of experience. The staff, teachers and assistants, are familiar with the activities through joint practical testing. It is up to the individual adult, both assistant and teacher, to further develop the ideas, and perhaps create new tasks to be implemented. The Language Jungle may also be used to make observations and mapping of certain children. This will guide the choice of tasks, but as all tasks have an element of play, any task may be fun and challenging to all children in the group. When the teachers use the equipment, they must reflect on what they do, how they use it, and how the children react to it. Here follows an observation made in the Language Jungle the summer of 2013:

The adult made three different tasks for a group of four four-yearolds to work with. Two of the boys immediately start working on a task on geometrical forms made up of colorful images. The adult talked a little about the names of the shapes and how to make figures with their help. The boys quickly move into a game involving 
the use of all the images to cover the background board. They have no wish to end this game, as they have figured out another way to do this activity. The adult goes to one of the hammocks and pulls out a task involving pictures from fairy tales. Using the pictures, the adult tells a story, while the children lie in the hammock listening. More children arrive, and soon fill the hammock. The children want to tell stories, and a girl has the first go; which works out well, with just a few interruptions by the input of others. "You may tell a story afterwards", says the girl who does not wish to be interrupted. This is fine for the other girl, as she afterwards tells the same story with new input from the listeners. It was time for food following this task, and there was time for no more tasks this session.

When the children cooperate retelling a story, they will together recreate more details and structure. The children that do not have so much to contribute with pay attention as listeners, learning the story from the others, and eventually will be able to tell the story themselves. Children working together solving a task, either they follow the instructions of the adults or their own, need to communicate, explain, and describe; thus, learning to cooperate and learn together.

In addition to organized activities, the language jungle invites nonorganized play and language activities. The apparatus form a trail where the children may climb, crawl, balance, and walk without putting their feet on the ground. A recurring tradition is games with rules, where many of the games are related to old traditions and customs the children have picked up from the adults or older children. The children also create their own performances and their own rules in the games, as in the following observation from the summer of 2010 :

Three boys climb around the jungle, with me on the ground watching. "You are the princess," a boy tells me. "Great," I answer before I understand it is not at all great. "You cannot come up until three minutes," he explains. It is the rule: touch the ground, then you will be a princess in this game; and then you have to wait a while before climbing up again.

Children learn a lot about communication and collaboration through games of rules, where they must explain, negotiate, and argue in advance of designing the rules for the game (Jagtøien and Hansen 2000, p. 152).

Between the trees, there are nets that form hammocks. The spaces of these hammocks or nets create a framework for role-playing with almost any theme, as in the following observation from the summer of 2011: 
Four boys, four and five years old, play animals in one of the hammocks.

"Once upon a time I was a cow," says Per.

"I was a baby cow", says Pål.

"Moo, moo, moo", says Per. "You were afraid of the large cow"

"I was an elephant," says Espen.

"No, you must be a tiger," says Pål.

"I can be an elephant," says Espen.

"But there can be only one cheetah," says Per. "Grr".

Some girls the same age are sitting in a nearby hammock. They would like to participate in the boys' game. They play women who live in the woods and are scared by the wild animals when they go for a walk.

Another time I visited, the nets were boats, with lava flowing underneath. The children had to be very careful not to fall on the ground and burn up. "From a language development perspective, role play is the most important form of play," says Anne Høigård [author's translation] (2013, p. 93). The role play is entirely dependent on the child's linguistic skills; it is the linguistic interaction between the children that carries the game. The children create a fiction together, and they must be able to perceive and follow the initiative of other children and take the initiative themselves (Høigård, 2013, p. 93).

In her doctoral dissertation, Lise Beate Estil highlights the important interaction between motor and linguistic competence, pointing to the importance of the playground for developing both motor and linguistic skills. While the youngest children learn languages from adults or older children, the play with their peers is the most important learning arena for the oldest children in the preschool. Children who have poor motor skills often experience difficulty being accepted as participants in play with other children. Similar problems are also reported for children who are inadequate in language skills. When children are excluded from interacting with other children, for either reason, this may have a negative effect on the development of both motor and language skills (Estil, 2002, p. 12). One affects the other, and thus the child is in a negative spiral. This spiral effect will also pose a social problem; the child will feel left outside, and so his or her social development is understimulated. The child may develop poor self-esteem, stay out of - or be held out of - the social community, which in turn leads to further delays in linguistic and motor development as well as social development (Løge, 2011, p. 12).

The Language Jungle is by no means complete, and is under continuous development. Since the staff built the jungle themselves, through their 
ownership they have a responsibility for maintenance and further development. Now, a few years later, much has happened in the Language Jungle; many of the old apparatus are strengthened, some are gone, and new ones have replaced them. The same applies to the language stimulation material, which is also work in constant development, depending on what is in focus at the preschool, and what ideas or needs are apparent.

The main subject of the interviews with the staff was which anticipations they had for the project before it started, and what they themselves think they learned during the project. Prior to the project, one of the informants was concerned that the activities in the Language Jungle might be run too much by the adults. After the project had ended, the informants were asked whether this was a current issue. All the informants responded with a no to the question, thus showing that the activities indeed are based on and carried out through play and joy. As adults in the preschool, it is important to appreciate the self-worth of play, and thus accommodate it. When asked what they have learned through the work on the project, there was a consensus that they have become much more aware of children's language development. They report that they have gained a greater focus on language and language stimulation; not only when they are in the Language Jungle, but in all daily tasks. They bring ideas and material from the Language Jungle, which are used in the preschool, or when they are on trips to other places. The staff get new ideas that are integrated into the ones they already have, and observation and language stimulation has become an even more natural part of everyday life. The staff at Tusenbein Preschool all agree that they have achieved their own goal of changing practice in relation to language-stimulating tasks outdoors.

\section{Conclusive comments}

Using fieldwork as a research method to evaluate the project Language Jungle, I have been able to establish that Tusenbein Preschool has reached its goals for the project. The starting point for this study was to look at how the preschool could create an environment outdoors where the children could develop both motor and language skills in a natural way. The Language Jungle facilitates for both planned, ad hoc, and in situ developing language activities, through the apparatus and accompanying tasks, which together form an integrated part of the climbing jungle. Early and good language stimulation is an important part of the preschool's content, and the playground is an important arena for developing both motor and linguistic skills (Estil 2002). Through the development of a challenging and exciting play area, they have created an arena that will be developing for the whole child; motoric, linguistically, intellectually, and also socially. 
The children have been given a challenging arena for play, where they first and foremost can play together and have fun.

While the project Language Jungle is about developing a good playground for the children, it is also about further development for the staff, both teachers and assistants, who have both created something and learned more about what work with language stimulation in preschool is. There is a consensus among the Tusenbein employees interviewed, that they were using the outdoor environment more consciously in language stimulation work after the project was completed, which was another goal for the project. Now, some years later, the project Language Jungle is in itself completed, but the Language Jungle is still in a continuous development, as was part of the initial plan.

\section{References}

Aukrust, V. G. (2005). Tidlig språkstimulering og livslang laering - en kunnskapsoversikt (Early language stimulation and lifelong learning - a knowledge overview). A report for the Ministry of Education and Research. Oslo, Norway.

Estil, L. B. (2002). Underlying deficits in motor and language impairments in children. Trondheim, Norway: Dr. polit. 2002, NTNU.

Gjems, L. and Løkken, G. (2011). Barns leering om språk og gjennom språk (Children learning about language and through language). Oslo, Norway: Cappelen Damm Akademisk.

Gubrium, J. F. and Holstein, J. A. (1997). The New Language and Qualitative Method. New York, USA: Oxford University Press.

Hammersley, M. and Atkinsen, P. (2004). Feltmetodikk (Field metodologi). Oslo, Norway: Gyldendal Akademisk forlag.

Hilmo, I., Holter, K. and Langholm, G. (2006). "Naturfagsnikksnakk" (Science chit chat). Oslo, Norway: Barnehagefolk (Preschool people) 4/2006.

Høigård, A. (2013). Barns språkutvikling muntlig og skriftlig (Children’s language development oral and written). Oslo, Norway: Universitetsforlaget.

Jagtøien, G. L. and Hansen, K. (2000). I bevegelse, sansemotorikk, leik, observasjon (In motion, sensory motor, play, observation). Oslo, Norway: Gyldendal Norsk forlag.

Law, J. (2007). After method, mess in social science research. Oxon, Great Britain: Routledge.

Løge, I. K. (2011). Språkvanskar og sosioemosjonelle vanskar (Language disorders and socio-emotional problems). In: Midthassel, Bru, Ertsvåg og Roland (red.): Sosiale og emosjonelle vansker: Barnehagens og skolens møte med sårbare barn og unge (Social and emotional problems: Preschools and schools meeting with vulnerable children and youths) (pp. 56-73). Oslo, Norway: Universitetsforlaget.

McNiff, J. (1995). Action Research for Professional Development. London, UK: Routledge.

Postholm, M. B. (red) (2006). Forsk med! Larere og forskere i laringsarbeid (Research! Teachers and researchers in learning). Oslo, Norway: N W Damm og søn. 
Sverdrup, S. (2002). Evaluering, faser, design og gjennomføring (Evaluation, phases, design and implementation). Bergen, Norway: Fagbokforlaget.

Tiller, T. (2006). Aksjonsforskning - forskende partnerskap i skolen (Action research researching partnership in the school). Kristiansand, Norway: Høyskoleforlaget.

Tusenbein (2009). Språkjungelen (Language Jungle). Appliance to Nordland Fylkeskommune (Nordland County Council). Norway.

Tusenbein Barnehage (2018). Tusenbein barnehage BA (Centipede Preschool). Mo i Rana: homepage. Retrieved from http://tusenbein.barnehage.no/Innhold/Side/93148 (28.04.18).

Vedeler, L. (2000). Observasjonsforskning i pedagogiske fag (Observation research in pedagogical subjects). Oslo, Norway: Gyldendal.

Vygotskij, L. (1978). Mind in Society: Development of Higher Psychological Processes. London, UK: Harvard University Press. 